Erratum

\title{
Erratum to "The Research on Strength and Deformation Behaviors of Buffer/Backfill Material under High-Temperature and High-Pressure Conditions"
}

\author{
Hao Chen $\left(\mathbb{D},{ }^{1,2,3}\right.$ Hai-Bo Lv $\left(\mathbb{D},{ }^{3}\right.$ Zheng-han Chen, ${ }^{4}$ and Yu-han Li $\mathbb{I D}^{1,2}$ \\ ${ }^{1}$ Geotechnical Engineering Department, Nanjing Hydraulic Research Institute, Nanjing, Jiangsu Province 210024, China \\ ${ }^{2}$ College of Civil and Transportation Engineering, Hohai University, Nanjing 210028, China \\ ${ }^{3}$ College of Civil Engineering, Guangxi University, Nanning 530004, China \\ ${ }^{4}$ Department of Architecture \& Civil Engineering, LEU, Chongqing 401311, China \\ Correspondence should be addressed to Hai-Bo Lv; lhb@glut.edu.cn
}

Received 3 April 2019; Accepted 4 April 2019; Published 28 October 2019

Copyright (c) 2019 Hao Chen et al. This is an open access article distributed under the Creative Commons Attribution License, which permits unrestricted use, distribution, and reproduction in any medium, provided the original work is properly cited.

In the article titled "The Research on Strength and Deformation Behaviors of Buffer/Backfill Material under HighTemperature and High-Pressure Conditions" [1], there was an error in the Acknowledgments section, which should be corrected as follows:

The authors are grateful to the National Key Research and Development Program of China (No. 2017YFC0405100), 300 the National Natural Science Foundation of China (No. 11672330, No. 11272353, No. 11072265, No. 51879166, 301 No. 51809181), the Nanjing Hydraulic Research Institute Foundation (Y317008), and the 302 Technology Demonstration Project of Ministry of Water Resources (SF-201704).

\section{References}

[1] H. Chen, H.-B. Lv, Z.-H. Chen, and Y.-H. Li, "The research on strength and deformation behaviors of buffer/backfill material under high-temperature and high-pressure conditions," $A d$ vances in Civil Engineering, vol. 2019, Article ID 5064690, 16 pages, 2019. 


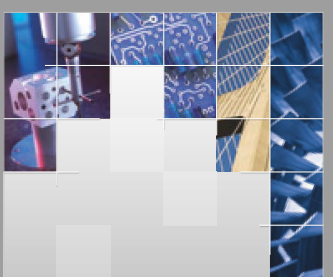

\section{Enfincering}
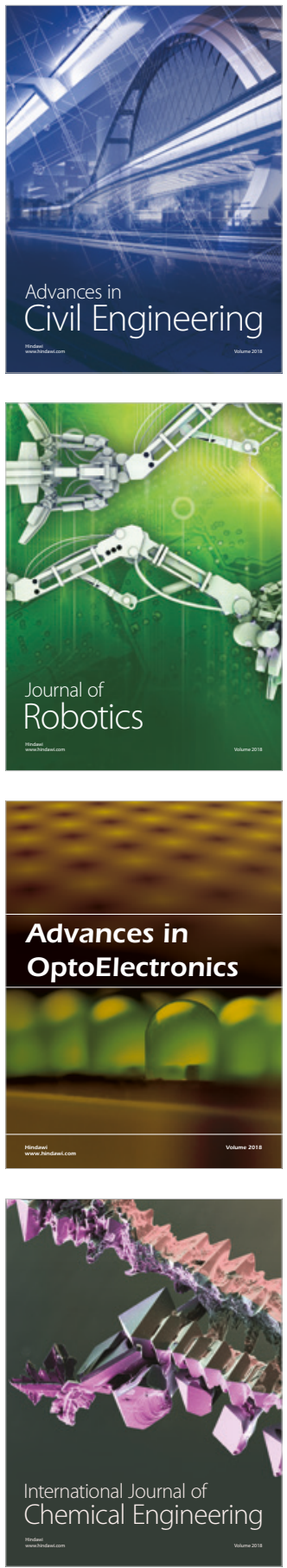

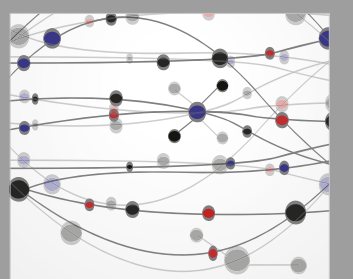

\section{Rotating \\ Machinery}

The Scientific World Journal

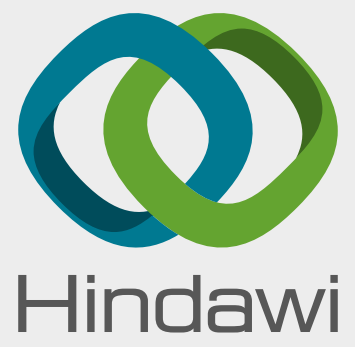

Submit your manuscripts at

www.hindawi.com
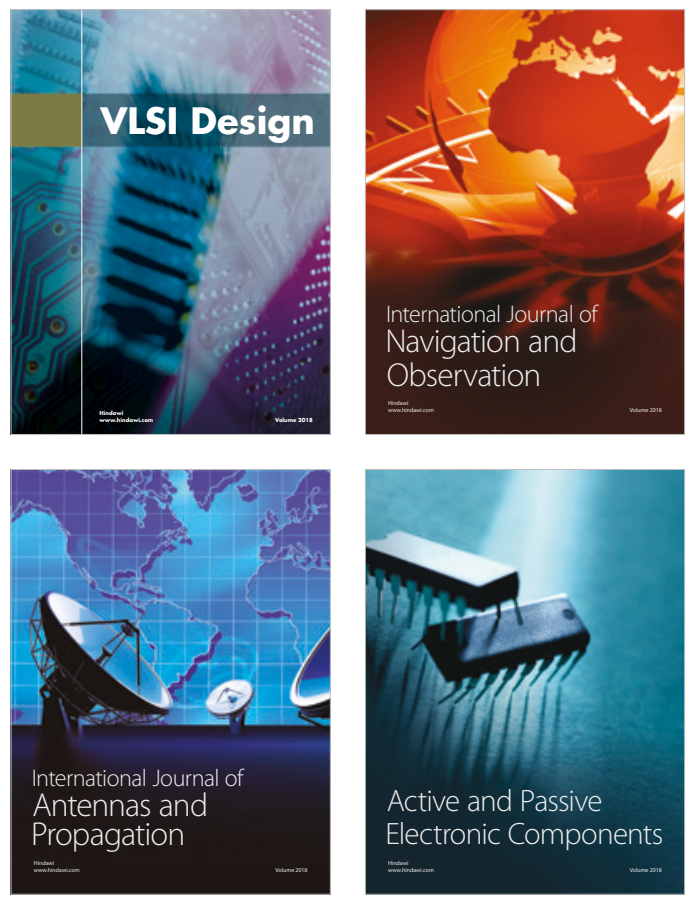
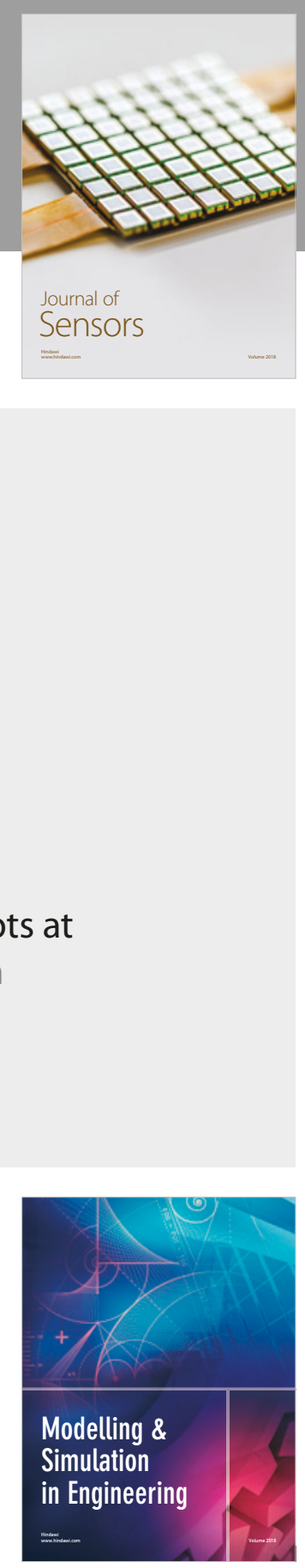

\section{Advances \\ Multimedia}
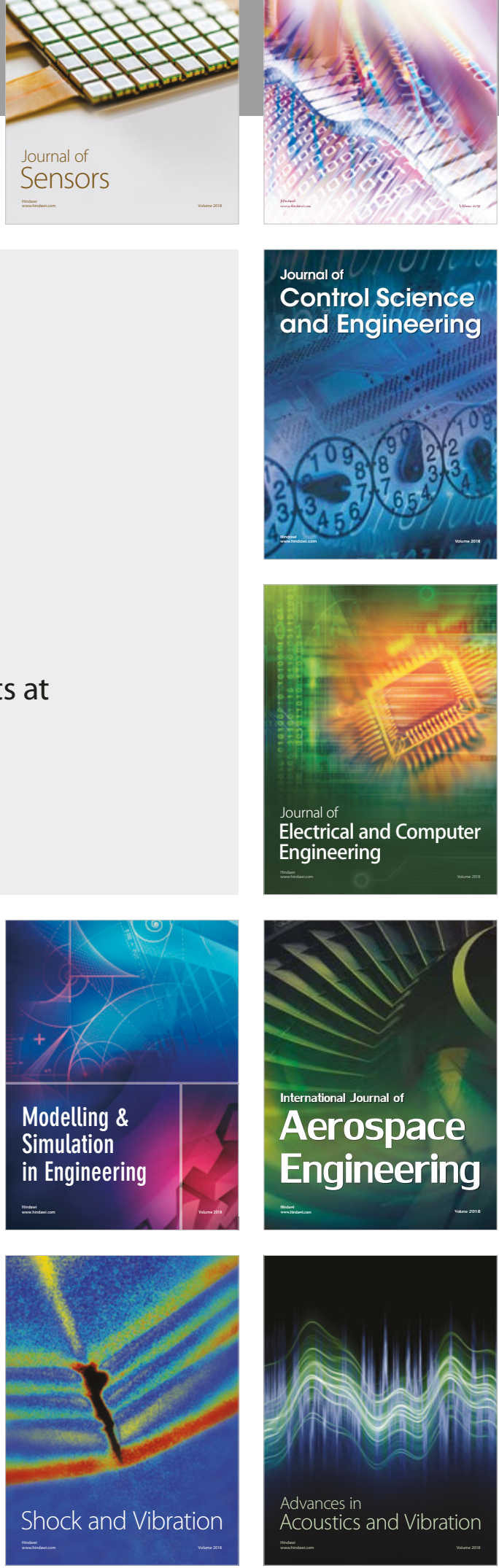